\title{
Effect of Various Meteorological Indices on the Yield and Nutrient Composition of Napiergrass ${ }^{1}$ (Pennisetum purpureum L.)
}

\author{
Modesto Capiel ${ }^{2}$
}

\begin{abstract}
Simple linear and multiple regression analyses were used to evaluate the effect of solar radiation, potential evapotranspiration, and other weather indices on the nutrient composition ( $\mathrm{N}$ and $\mathrm{K}$ ) and yield of napiergrass (Pennisetum purpureum), in an attempt to better understand previously published results on the effect of harvest frequency, supplemental irrigation, and nitrogen fertilization on the yield of this forage. The inverse relationships between yields and nutrient composition (dilutional effects), previously reported as more significant for the frequently-harvested forage, were also evident in the present study. An inverse and more significant relation between nutrient composition and evaporative-demand indices was again observed for the frequently-harvested forage.

Inasmuch as both the yield-nutrients and the nutrients-weather relations are inverse, positive relations should be expected between yields and weather. This was the case, and more significantly so for the frequentlyharvested and irrigated forage yields than for the less frequently harvested forages as a function of evaporative-demand indices.

The use of more than one weather index in multiple regression analysis appeared to improve significantly the prediction of irrigated forage yields, especially of those under the low-N regime. A harvest-frequency factor $\left(h_{f}\right)$ contributed further toward the accuracy of the prediction of irrigated forage yields. This confirms the overall effect of harvest frequency on forage yields and the significant harvest frequency-irrigation interaction.
\end{abstract}

\section{INTRODUCTION}

The influence of climate (average long-time meteorological conditions) on the yield of plants has limited the economic production of specific crops to certain geographical areas. The influence of weather (day-by-day meteorological conditions) on plant growth and development has received less attention than has climate, particularly in the lower latitudes. It is certain, however, that the weather during a specific growing season significantly affects the crop yields in that season.

Possibly the lack of information stems from the fatalistic attitude that little can be done about the weather. Crop responses to weather, however, are interrelated to soil properties and management practices such as fertilization and irrigation. Although extensive modifications of weather remain economically and/or technologically impossible, management practices can be adjusted to make the best use of the prevailing conditions if the optimum are defined.

${ }^{1}$ Manuscript submitted to Editorial Board March 10, 1976.

${ }^{2}$ Agricultural Climatologist, Agricultural Experiment Station, Mayagüez Campus, University of Puerto Rico, Río Piedras, P.R. 
Gaiza et al. (4) reported that $69 \%$ more dry matter accumulated with a light intensity of 4000 foot-candles than with 1000 foot-candles. They also found that the proper combinations of light intensity, temperature, and length of growing period are important in optimizing plant growth.

Weihing (9) analyzed dry matter yields of ryegrass under field. conditions as a function of air temperature, solar radiation, and their combined effects. He obtained simple correlation coefficients of 0.84 and 0.74 for temperature and solar radiation, respectively.

Hart and Burt (5) reported that when combined effects of harvest date, accumulated precipitation, accumulated solar radiation, and accumulated degree-days above $4.5^{\circ} \mathrm{C}$ were correlated with accumulated yields, $R^{2}$ values of $0.96,0.91$, and 0.93 were obtained for oats, rye, and wheat, respectively. Wheat yields were not significantly correlated with either precipitation or radiation.

However, a major problem in crop-weather research is the selection of the meteorological elements that characterize the weather and exert influence on the water economy and photosynthesis of plants. It is known that the latter is the biological growth process mainly affected by the environment.

There has been little weather-crop research for forage crops growing in the field at lower latitudes. Consequently, an investigation was conducted in the Gurabo Agricultural Experiment Substation to evaluate the effects of weather on the yield and nutrient composition of forage. The effect of harvest frequency, irrigation, and $\mathrm{N}$ fertilization rate on the yield and quality of the forage are reported elsewhere (3). For this weather approach to the investigation the data from five additional harvests have been included in the study.

\section{EXPERIMENTAL METHODS}

The experiment was conducted at the Agricultural Experiment Station, Gurabo, Puerto Rico. The mean annual precipitation (65-year average) at the experimental site is $160 \mathrm{~cm}$. The mean annual temperature is $25^{\circ} \mathrm{C}$, with an average range of $5^{\circ} \mathrm{C}$ between the mean temperatures of the warmest and the coldest month of the year. The daily temperature range may rise to $18^{\circ} \mathrm{C}$, although normally it is no more than $12^{\circ} \mathrm{C}$.

The soil is a grayish-brown silty clay loam, mixed with some coarse material of alluvial and colluvial origin. At a depth of 30 to $40 \mathrm{~cm}$ the soil texture becomes a little heavier, with some rust-brown and gray mottling. A layer of gravel and coarse sand is found at 60 to $75 \mathrm{~cm}$ below the soil surface.

In late January, 1965, mature stem cuttings of napiergrass, variety Merker, were laid in furrows $1 \mathrm{~m}$ apart and completely covered with 
about $5 \mathrm{~cm}$ of soil. The experimental plots were irrigated as needed to insure a uniform stand until a first general harvest on April 26, 1965. These forage yields and those of the first differential harvests on June 10 and 25 (45- and 60-day harvest) were discarded in order to establish a more reliable plant population. The differential harvest extended until October 1966.

A split-split experimental plot design was used with two harvest intervals $(H)$ constituting the main plots. Within each main plot, two irrigation regimes $(I)$ or subplots were established. These were further subdivided into sub-sub-plots or basic experimental units to allow for two $\mathrm{N}$ levels. Each basic experimental unit was $5.5 \times 11 \mathrm{~m}$ and contained six rows of napiergrass. The treatments were replicated three times.

The harvest intervals selected were: 45 days $\left(H_{1}\right)$, and 60 days $\left(H_{2}\right)$. The cutting height was maintained at around $8 \mathrm{~cm}$ from the ground. At harvest, outside rows and $1 \mathrm{~m}$ guard swaths were discarded.

The irrigation regimes were: application of irrigation water whenever the soil water potential at about $10 \mathrm{~cm}$ depth reached $-0.7 \mathrm{bar}\left(I_{1}\right)$, and no irrigation $\left(I_{0}\right)$. Irrigation was applied individually to each experimental unit by the check flooding method, and the water potential was estimated using calibrated cylindrical gypsum blocks. Table 1 presents the number of irrigations and amount of water added to each $\mathbb{I}_{1}$ experimental unit, in addition to the rainfall received and distributed between harvest dates.

The two $\mathrm{N}$ application rates were: $560 \mathrm{~kg}$ of $\mathrm{N} /$ ha yearly $\left(\mathrm{N}_{1}\right)$, and $1120 \mathrm{~kg}$ of $\mathrm{N} /$ ha yearly $\left(\mathrm{N}_{2}\right)$. These amounts were split into 8 and 11 equal applications, which were made at the beginning of each harvest period, for the 60- and 45-day harvest intervals, respectively.

Representative forage samples were obtained at each harvest for dry matter determinations (oven-dry at $70-80^{\circ} \mathrm{C}$ for $24 \mathrm{~h}$ ). The dry samples were then analyzed to determine the amounts of $\mathrm{N}, \mathrm{P}, \mathrm{K}, \mathrm{Ca}$, ash, and fiber in the forage. All the results are reported in percentages, on a dry-weight basis. The chemical composition of the forage has been reported by Capiel (2).

Meteorological data were recorded continuously at the experimental site. Total incoming solar radiation was measured with an Eppley pyrheliometer and net radiation with a miniature net radiometer. Air temperature and humidity were recorded with a hygrothermograph, and wind movement was measured with an anemometer. Daily evaporation and rainfall were measured with a standard U.S. Weather Bureau plastic open pan and a rain gauge, respectively.

The meteorological factors discussed here in relation to yield and nutrient composition of the forage are: solar energy $\left(R_{i}\right)$, air tempera- 
TABLE 1. - Number of irrigations and amount of water applied within each growth period between harvest dates, and rainfall distribution within the corresponding periods

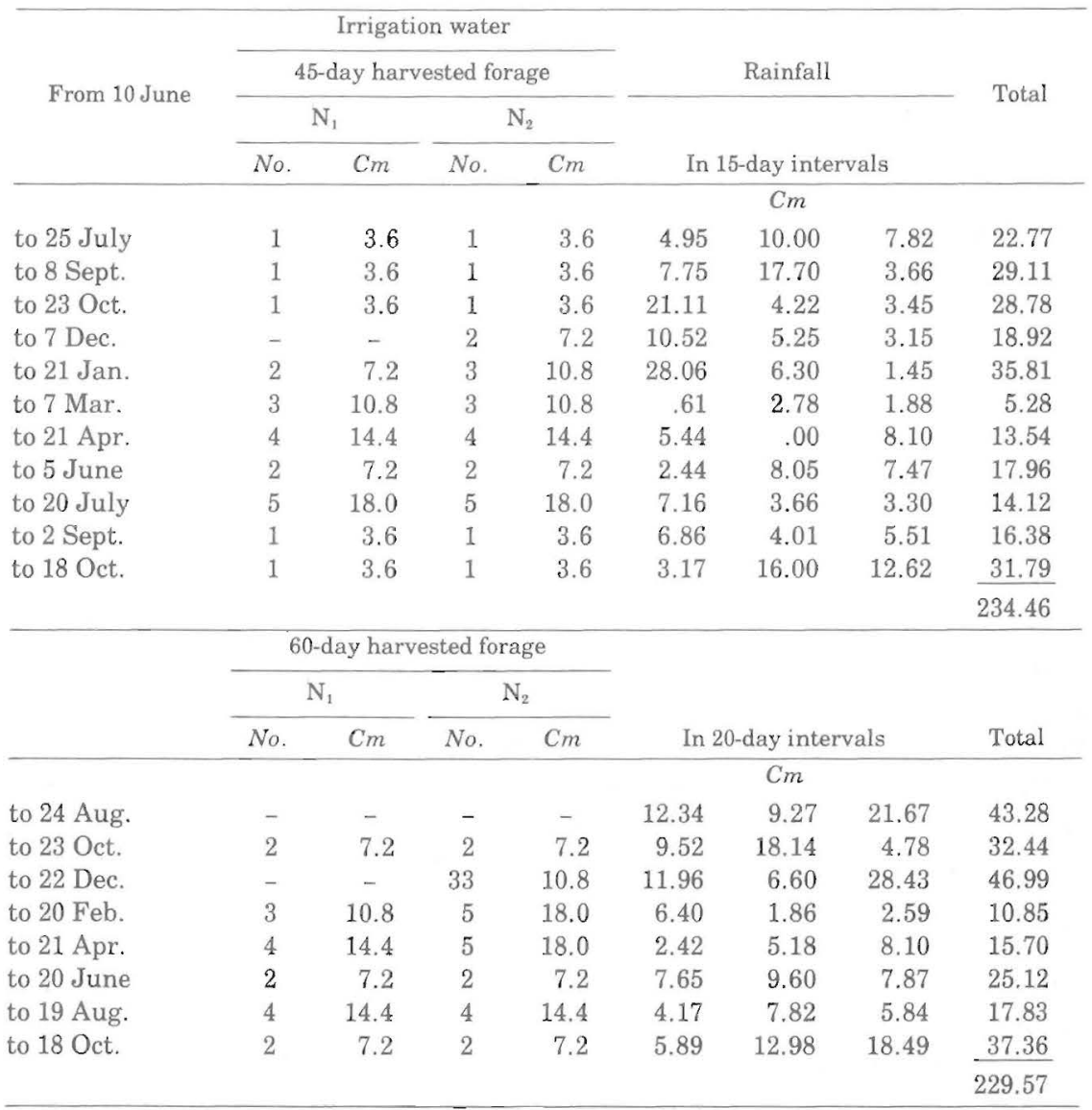

ture $(T a)$, wind speed $(u)$, air saturation deficit $\left(e_{d}\right)$, potential evapotranspiration $\left(E_{t}\right)$, and pan evaporation $\left(E_{0}\right)$. The air saturation deficit was derived from the mean relative humidity $(R H)$, fitted into the following equation:

$$
e_{d}=e_{s}-e_{s}(R H)
$$

where $e_{s}$ is the saturation vapor pressure of the air corresponding to the mean air temperature $\left(T_{a}\right)$ obtained from tables.

Potential evapotranspiration estimates corresponding to the periods between harvests were determined by using the Penman (7) equation, as modified by Tanner and Pelton (8). This modification takes into account the surface roughness as influenced by the crop height. Forage 
height measurements were taken within each period and averaged for the desired periods.

The influence of each weather component on the nutrient composition and yield of the forage was evaluated by simple regression analysis. Multiple regression was used to evaluate further the joint influence of the various weather factors on yields, and to determine which combination of factors could best be used to predict forage yield. The independently measured weather factors $\left(R_{i}, T_{a}, u\right.$, and $\left.e_{d}\right)$ were introduced into the multiple regression equation in decreasing order of influence on the forage yields as determined by simple regression. The multiple regression equation employed as a model was

$$
Y_{H I N}=a_{0}+b_{1} X_{1}+b_{2} X_{2}+b_{3} X_{3}+b_{4} X_{4}
$$

where, $Y_{H I N}$ represents the dry matter yield of any of the eight experimental units previously described, and averaged for three replications. $X_{1}$ through $X_{4}$ represent the measurements of the weather elements $\left(R_{i}, T_{a}, u\right.$, and $\left.e_{d}\right)$ in decreasing order of influence as determined by their simple correlation coefficients with yield; and $b_{1}$ through $b_{4}$ represent the partial regression coefficients of $X_{1}$ through $X_{4}$. Weather elements were again ordered by placing first in the equation those terms that made the most significant contribution in multiple regression, as evaluated by the resulting $F$ values. All factors that did not make a significant contribution to the multiple regression were dropped from the equation, except those which, although not making a significant contribution by themselves, exerted a significant influence when combined with some other factors.

Multiple regression was also used to explain forage monthly yields. The monthly yield was calculated by arbitrarily assuming equal daily weight gains within each harvest period. This was done so that yields from the two harvest intervals could be estimated and included in the multiple regression study. In doing so, a harvest frequency factor, $\mathrm{H}_{f}$, was included in the analysis, along with the weather factors. The $H_{f}$ level for the 45-day interval was defined as -1, and that for the 60-day interval as +1 . Thus, by using the $H_{f}$ factors of -1 and 1 in the multiple regression equation, depending on the harvest interval, it was possible to determine whether harvest interval contributed significantly to the explanation of the yield by the regression equation fitted to the data. If the yields of either frequency (45- or 60-day) consistently deviated negatively or positively from the mean, the $t$ value associated with the harvest interval would be significant.

\section{RESULTS AND DISCUSSION}

Tables 2 and 3 summarize the forage yields, their $\mathrm{N}$ and $\mathrm{K}$ composition on the indicated harvest dates, and the corresponding mean values 
TABLE 2. - Yields, $N$ and $K$ values of the 45-day harvested forage, and weather data between harvests

\begin{tabular}{|c|c|c|c|c|c|c|c|c|c|c|}
\hline Harvest day & Units & $\mathrm{I}_{0} \mathrm{~N}_{1}$ & $\mathrm{I}_{0} \mathrm{~N}_{2}$ & $\mathrm{I}_{1} \mathrm{~N}_{1}$ & $\mathrm{I}_{1} \mathrm{~N}_{2}$ & $R i$ & $T a$ & $u$ & $e_{d}$ & $E t$ \\
\hline & & & & & 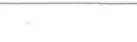 & $M m / d$ & ${ }^{\circ} \mathrm{C}$ & $K m / d$ & $M b$ & $M m / d$ \\
\hline \multirow[t]{2}{*}{$7 / 25 / 65$} & t/ha & 4.88 & 5.44 & 4.81 & 4.84 & 8.20 & 25.3 & 55.4 & 5.61 & 4.49 \\
\hline & $\% \mathrm{~N}, \% \mathrm{~K}$ & $1.43-3.60$ & $2.24-3.45$ & $1.53-3.83$ & $2.16-3.49$ & & & & & \\
\hline \multirow[t]{2}{*}{$9 / 8 / 65$} & t/ha & 5.79 & 6.78 & 5.62 & 6.42 & 8.08 & 26.2 & 54.2 & 4.69 & 4.34 \\
\hline & $\% \mathrm{~N}, \% \mathrm{~K}$ & $1.43-3.63$ & $1.89-2.87$ & $1.51-3.64$ & $1.92-3.13$ & & & & & \\
\hline \multirow[t]{2}{*}{$10 / 23 / 65$} & t/ha & 4.68 & 5.18 & 5.04 & 4.75 & 7.41 & 24.8 & 38.9 & 3.85 & 3.47 \\
\hline & $\% \mathrm{~N}, \% \mathrm{~K}$ & $1.88-3.63$ & $2.47-3.14$ & $1.91-3.79$ & $2.33-3.15$ & & & & & \\
\hline \multirow[t]{2}{*}{$12 / 7 / 65$} & t/ha & 3.84 & 4.50 & 3.64 & 4.06 & 6.92 & 23.2 & 35.8 & 3.95 & 3.10 \\
\hline & $\% \mathrm{~N}, \% \mathrm{~K}$ & $2.09-4.16$ & $2.79-3.49$ & $2.05-4.45$ & $2.63-3.71$ & & & & & \\
\hline \multirow[t]{2}{*}{$1 / 21 / 66$} & t/ha & 2.96 & 3.38 & 2.69 & 2.95 & 6.49 & 23.5 & 35.0 & 5.38 & 2.91 \\
\hline & $\% \mathrm{~N}, \% \mathrm{~K}$ & $1.98-4.00$ & $2.95-3.75$ & $2.00-4.34$ & $2.88-3.83$ & & & & & \\
\hline \multirow[t]{2}{*}{$3 / 7 / 66$} & t/ha & 1.50 & 2.03 & 3.20 & 3.45 & 7.59 & 22.6 & 58.9 & 4.50 & 3.62 \\
\hline & $\% \mathrm{~N}, \% \mathrm{~K}$ & $1.82-3.95$ & $2.50-3.27$ & $1.78-4.08$ & $2.58-3.38$ & & & & & \\
\hline \multirow[t]{2}{*}{$4 / 21 / 66$} & t/ha & 3.32 & 4.18 & 4.62 & 6.17 & 8.28 & 24.0 & 56.6 & 5.88 & 4.38 \\
\hline & $\% \mathrm{~N}, \% \mathrm{~K}$ & $1.67-3.89$ & $2.05-2.78$ & $1.56-3.82$ & $2.27-2.93$ & & & & & \\
\hline \multirow[t]{2}{*}{$6 / 5 / 66$} & t/ha & 5.96 & 6.51 & 5.26 & 4.97 & 8.35 & 24.4 & 83.2 & 5.71 & 4.80 \\
\hline & $\% \mathrm{~N}, \% \mathrm{~K}$ & $1.58-3.56$ & $2.13-2.47$ & $1.32-3.32$ & $1.93-2.34$ & & & & & \\
\hline \multirow[t]{2}{*}{$7 / 20 / 66$} & t/ha & 4.66 & 5.85 & 5.24 & 6.21 & 8.19 & 25.5 & 72.5 & 4.60 & 4.54 \\
\hline & $\% \mathrm{~N}, \% \mathrm{~K}$ & $1.57-2.08$ & $2.25-2.25$ & $1.40-3.03$ & $2.19-2.21$ & & & & & \\
\hline \multirow[t]{2}{*}{$9 / 2 / 66$} & t/ha & 5.10 & 5.40 & 4.68 & 4.99 & 8.27 & 26.2 & 61.2 & 5.14 & 4.55 \\
\hline & $\% \mathrm{~N}, \% \mathrm{~K}$ & $1.87-3.28$ & $2.21-2.29$ & $1.72-3.10$ & $2.04-2.40$ & & & & & \\
\hline \multirow[t]{2}{*}{$10 / 18 / 66$} & t/ha & 4.51 & 5.04 & 4.01 & 4.68 & 7.51 & 25.5 & 46.2 & 4.50 & 3.75 \\
\hline & $\% \mathrm{~N}, \% \mathrm{~K}$ & $2.21-4.18$ & $2.47-2.75$ & $1.70-3.06$ & $2.16-2.63$ & & & & & \\
\hline
\end{tabular}


TABLE 3. - Yields, $N$ and $K$ percentage contents of the 60-day harvested forage, and weather data between harvests

\begin{tabular}{|c|c|c|c|c|c|c|c|c|c|c|}
\hline Harvest day & Units & $\mathrm{I}_{0} \mathrm{~N}_{1}$ & $\mathrm{I}_{0} \mathrm{~N}_{2}$ & $I_{1} N_{1}$ & $\mathrm{I}_{1} \mathrm{~N}_{2}$ & $R i$ & $T a$ & $u$ & $e_{d}$ & $E t$ \\
\hline & & & & & & $\mathrm{Mm} / \mathrm{d}$ & ${ }^{\circ} \mathrm{C}$ & $\mathrm{Km} / \mathrm{d}$ & $M b$ & $M m / d$ \\
\hline \multirow[t]{2}{*}{$8 / 24 / 65$} & t/ha & 8.41 & 8.67 & 7.99 & 9.52 & 7.90 & 25.3 & 50.6 & 4.64 & 4.14 \\
\hline & $\% \mathrm{~N}, \% \mathrm{~K}$ & $1.21-2.74$ & $1.57-2.41$ & $1.25-2.95$ & $1.56-2.72$ & & & & & \\
\hline \multirow[t]{2}{*}{$10 / 23 / 65$} & t/ha & 7.53 & 7.49 & 7.34 & 8.74 & 7.96 & 25.5 & 43.4 & 4.31 & 4.01 \\
\hline & $\% \mathrm{~N}, \% \mathrm{~K}$ & $1.36-2.29$ & $1.75-1.88$ & $1.39-2.39$ & $1.68-2.20$ & & & & & \\
\hline \multirow[t]{2}{*}{$12 / 22 / 65$} & t/ha & 6.20 & 6.69 & 6.65 & 7.07 & 6.72 & 24.0 & 32.3 & 4.51 & 3.10 \\
\hline & $\% \mathrm{~N}, \% \mathrm{~K}$ & $1.60-2.89$ & $2.01-2.15$ & $1.57-2.48$ & $1.95-2.37$ & & & & & \\
\hline \multirow[t]{2}{*}{$2 / 20 / 66$} & t/ha & 3.96 & 4.89 & 5.16 & 6.39 & 6.89 & 22.6 & 49.3 & 4.85 & 3.36 \\
\hline & $\% \mathrm{~N}, \% \mathrm{~K}$ & $1.59-3.22$ & $2.23-2.48$ & $1.64-2.86$ & $2.10-2.52$ & & & & & \\
\hline \multirow[t]{2}{*}{$4 / 21 / 66$} & t/ha & 4.26 & 5.43 & 7.28 & 8.40 & 8.44 & 23.9 & 58.1 & 5.43 & 4.59 \\
\hline & $\% \mathrm{~N}, \% \mathrm{~K}$ & $1.41-3.21$ & $1.79-3.17$ & $1.33-2.75$ & $1.85-2.38$ & & & & & \\
\hline \multirow[t]{2}{*}{$6 / 20 / 66$} & t/ha & 8.59 & 8.96 & 7.42 & 8.08 & 8.37 & 24.8 & 80.5 & 5.88 & 4.92 \\
\hline & $\% \mathrm{~N}, \% \mathrm{~K}$ & $1.52-2.39$ & $2.10-2.06$ & $0.99-2.17$ & $1.39-1.75$ & & & & & \\
\hline \multirow[t]{2}{*}{$8 / 19 / 66$} & $\mathrm{t} / \mathrm{ha}$ & 6.89 & 8.29 & 8.22 & 9.43 & 8.20 & 26.0 & 61.6 & 4.68 & 4.74 \\
\hline & $\% \mathrm{~N}, \% \mathrm{~K}$ & $1.46-2.39$ & $2.06-2.11$ & $1.69-1.97$ & $1.81-1.95$ & & & & & \\
\hline \multirow[t]{2}{*}{$10 / 18 / 66$} & t/ha & 6.32 & 7.30 & 7.12 & 7.48 & 7.69 & 25.8 & 55.0 & 4.58 & 4.23 \\
\hline & $\% \mathrm{~N}, \% \mathrm{~K}$ & $1.53-2.41$ & $2.13-2.34$ & $1.25-1.87$ & $1.79-1.98$ & & & & & \\
\hline
\end{tabular}


of various weather parameters for the 45- and 60-day harvest frequency, respectively. The rainfall data are given in table 1. Upon visual inspection of the data in tables 2 and 3 two features relative to the 45day forage data become apparent: First, while the $\mathrm{N}$ and $\mathrm{K}$ contents followed similar time-course trends (even on the 60-day harvested grass), the high $\mathrm{N}$ fertilization treatment $\left(\mathrm{N}_{2}\right)$ depressed the $\mathrm{K}$ content of the more frequently-harvested forage $\left(\mathrm{H}_{1} \mathrm{~N}_{2}\right)$, relative to that of the $\mathrm{H}_{1} \mathrm{~N}_{1}$ forage. Second, in the more frequently-harvested forage (table 2), both $\mathrm{N}$ and $\mathrm{K}$ percent composition attained peak values in both the December 7 and January 21 harvests when evaporative demands were least. From then on their values decreased until the July 20 harvest when evaporative demands were highest. Neither observation becomes evident for the 60-day frequency data. Possibly, nutritional aspects were confused with management (harvest frequency) and environmental factors.

The correlation coefficients between the $\mathrm{N}$ and $\mathrm{K}$ contents of the forage, and various weather indices $\left(E_{t}, R_{i}, T_{a}\right)$ are shown in table 4 for all the treatment combinations. They were of an inverse linear nature in all but one instance. While the $\mathrm{N}$ and $\mathrm{K}$ of the 45-day harvests were significantly correlated with $R_{i}, E_{t}$, and $T_{a}$, the degree of correlation for the 60-day harvests was poor. Thus, harvest frequency appears to be the source of a marked contrast in the weather-nutrientcomposition relationships of the forage. The inverse correlations between $R_{i}$ and $E_{t}$ as weather indices, and $\mathrm{N}$ composition of the 45-day harvest data, appear to be the most significant. Because $\mathrm{K}$ content was so severely affected by $\mathrm{N}$ fertilization, its response to environment was less sensitive than that of $N$. The weather-nutrient relationships deserve comment for two reasons: 1) The decreasing $\mathrm{N}$ and $\mathrm{K}$ percent composition, with increasing evaporative demands, was more pronounced at the 45-day frequency, which also exhibited a more significant decrease in $\mathrm{N}$ and $\mathrm{K}$ percent composition as a function of the forage yield by harvests. A similar response has been reported previously (1). 2) This general agreement between yields and nutrients, and the latter's decrease in percent composition with respect to some weather indices should offer clues as to the lack of yield response to irrigation at 45-day frequency harvest.

Air temperature was not generally related to $\mathrm{N}$ or $\mathrm{K}$ content.

Thus, it appears that nutritional aspects related to the mineral uptake of the forage were altered by environmental factors when more frequent harvest regimes were imposed. Under 60-day harvests the grass appears to be a more efficient manufacturing plant with increased ability to benefit from supplemental irrigation. Because the forage remained in a well-developed vegetative stage for a longer period 
before harvest it is likely that the plant could better supply the roots with carbohydrates and organic acids required for the metabolic and assimilation processes preceding new root development. Lenkel (6) noted that the initiation in early spring of new top and root growth in alfalfa, caused partial depletion of organic reserves stored in the roots the previous season. The amount of stored reserves depended on the maturity of top growth. Thus, Lenkel concludes that the frequent

TABLE 4.-Correlation coefficients of $N$ and $K$ percentages of the forage as a function of the mean values of potential evapotranspiration $\left(E_{v}\right)$, solar radiation $\left(R_{i}\right)$, and air temperature $\left(T_{a}\right)$

\begin{tabular}{|c|c|c|c|c|}
\hline \multirow{2}{*}{ Correlated variable } & \multicolumn{4}{|c|}{ Treatment identification } \\
\hline & $\mathrm{I}_{0} \mathrm{~N}_{\mathrm{t}}$ & $\mathrm{I}_{0} \mathrm{~N}_{2}$ & $I_{1} N_{1}$ & $\mathrm{I}_{1} \mathrm{~N}_{2}$ \\
\hline \multicolumn{5}{|l|}{$N$ vs. $E_{t}$} \\
\hline $\mathrm{H}_{1}$ & $-.725^{*}$ & $-.894^{* *}$ & $-.923^{* *}$ & $-.875^{* *}$ \\
\hline $\mathrm{H}_{2}$ & -.343 & -.123 & -.523 & -.668 \\
\hline \multicolumn{5}{|l|}{ N vs. $R_{i}$} \\
\hline $\mathrm{H}_{1}$ & $-.736 * *$ & $-.927^{* *}$ & $-.877 * *$ & $-.863^{* *}$ \\
\hline $\mathrm{H}_{2}$ & -.532 & -.339 & -.398 & -.678 \\
\hline \multicolumn{5}{|l|}{$\mathrm{N}$ vs. $T_{a}$} \\
\hline $\mathrm{H}_{1}$ & -.338 & $-.613^{*}$ & $-.627^{*}$ & $-.784 * *$ \\
\hline $\mathrm{H}_{2}$ & -.448 & -.291 & -.257 & -.576 \\
\hline \multicolumn{5}{|l|}{ K vs. $E_{t}$} \\
\hline $\mathrm{H}_{1}$ & -.563 & $-.762 * *$ & $-.707 *$ & $-.738^{* *}$ \\
\hline $\mathrm{H}_{2}$ & -.450 & +.045 & -.420 & -.592 \\
\hline \multicolumn{5}{|l|}{$\mathrm{K}$ vs. $R_{i}$} \\
\hline $\mathrm{H}_{1}$ & -.513 & $-.747 * *$ & $-.670^{*}$ & $-.708^{*}$ \\
\hline $\mathrm{H}_{2}$ & -.398 & -.161 & -.253 & -.431 \\
\hline \multicolumn{5}{|l|}{$\mathrm{K}$ vs. $T_{a}$} \\
\hline $\mathrm{H}_{1}$ & -.480 & -.600 & $-.676^{*}$ & -.554 \\
\hline $\mathrm{H}_{2}$ & -.155 & -.459 & -.653 & -.470 \\
\hline
\end{tabular}

* Significant at the $5 \%$ level. $\mathrm{H}_{1}$ has 9 d.f. and $\mathrm{H}_{2}$ has 6 d.f.

** Significant at the $1 \%$ level.

cutting of alfalfa at immature stages of growth caused a continuous reduction of organic reserves.

Table 4 shows that there is an inverse relation between nutrient composition and some weather components (irrespective of significance). Since the correlation between yield and nutrients, discussed in a previous paper (3) is also inverse, the correlation between the weather indices and yield must be positive if the yield-nutrition-weather relationships are consistent with the statistical results. All the forage yields were directly proportional to the evaporative-demands weather indices, and to the air temperature as well. Only air temperature related significantly to nearly all the forage yields (table 5). Evapora- 
tive-demand indices $\left(E_{t}, R_{i}\right.$, and $E_{0}$ ) exhibited a significant correlation mainly with the irrigated, frequently-harvested forage $\left(H_{1} I_{1}\right)$.

While all the irrigated forage exhibited significant correlation with solar radiation, the non-irrigated forage yields correlated rather poorly with this weather index. The change in yields with a unit change in solar energy (regression coefficients) was also greater for the irrigated forage. On the other hand, the response of the non-irrigated forage yields to equal increments of air temperature was greater than that of the irrigated forage yields. Air temperature and solar radiation were used as independent weather indices because they were not significantly correlated.

TABLE 5.-Correlation and regression coefficients of yield as a function of corresponding weather indices averaged by harvest periods

\begin{tabular}{|c|c|c|c|c|c|c|c|c|}
\hline \multirow{2}{*}{$\begin{array}{l}\text { Treat- } \\
\text { ment }\end{array}$} & \multicolumn{4}{|c|}{ Correlation coefficient $(r)$} & \multicolumn{4}{|c|}{ Regression coefficient } \\
\hline & Ta & $R i$ & Eo & Et & $R i$ & $T a$ & Eo & Et \\
\hline \multicolumn{9}{|c|}{ With supplemental irrigation, $I_{1}$} \\
\hline $\mathrm{H}_{1} \mathrm{I}_{1} \mathrm{~N}_{1}$ & $.725^{*}$ & $.788 * *$ & $.822^{* * *}$ & $.785^{* *}$ & 1.18 & 0.56 & 0.93 & 1.13 \\
\hline $\mathrm{H}_{1} \mathrm{I}_{1} \mathrm{~N}_{2}$ & $.663^{*}$ & $.766^{* *}$ & $.749 * *$ & $.742 * *$ & 1.36 & .60 & 1.01 & 1.27 \\
\hline $\mathrm{H}_{2} \mathrm{I}_{1} \mathrm{~N}_{1}$ & $.846^{* *}$ & $.736^{*}$ & $.728^{*}$ & .700 & 1.07 & .69 & .86 & 1.02 \\
\hline $\mathrm{H}_{2} \mathrm{I}_{1} \mathrm{~N}_{2}$ & $.716^{*}$ & $.736^{*}$ & $.709 *$ & .638 & 1.26 & .69 & .99 & 1.10 \\
\hline Mean & & & & & 1.22 & .63 & .95 & 1.13 \\
\hline \multicolumn{9}{|c|}{ Without supplemental irrigation, $I_{0}$} \\
\hline $\mathrm{H}_{1} \mathrm{I}_{0} \mathrm{~N}_{1}$ & $.795^{* *}$ & .508 & $.613^{*}$ & .597 & 1.06 & .85 & .97 & 1.20 \\
\hline $\mathrm{H}_{1} \mathrm{I}_{0} \mathrm{~N}_{2}$ & $.794^{* *}$ & .549 & $.633^{*}$ & $.631^{*}$ & 1.21 & .90 & 1.05 & 1.33 \\
\hline $\mathrm{H}_{2} \mathrm{I}_{0} \mathrm{~N}_{1}$ & .700 & .375 & .520 & .387 & 1.00 & 1.04 & 1.13 & 1.04 \\
\hline $\mathrm{H}_{2} \mathrm{I}_{0} \mathrm{~N}_{2}$ & $.786^{*}$ & .470 & .619 & .532 & 1.07 & 1.00 & 1.15 & 1.22 \\
\hline Mean & & & & & 1.08 & .95 & 1.07 & 1.20 \\
\hline
\end{tabular}

* Significant at the $5 \%$ level.

** Significant at the $1 \%$ level.

In this study air temperature was the most useful weather parameter in predicting all the forage yields. Since yield is the ultimate expression of net assimilation, this implies that of the weather elements tested, air temperature is the best index of net assimilation rate.

On the other hand, sunlight, being the source of energy for plant life, might be expected to be highly correlated with the forage yields. Nevertheless, the correlation of yield versus solar energy was significant only with irrigated forage.

A reasonable explanation of why solar energy generally did not correlate as significantly as air temperature with all forage yields can be found by first looking at the effect of solar radiation on temperature and then comparing it with its effect on plants. The influence of solar 
radiation on air temperature is moderated to a great extent by air humidity in the tropics, in addition to the moderating effect of wind movement. Thus, air temperature integrates to some extent the effect of humidity and wind, counterbalancing the opposite effect of solar radiation on warming the air. In plants, these effects are expressed similarly in leaf temperature, transpiration, and photosynthesis. Therefore, it should not be surprising to obtain a more generally significant correlation of air temperature with forage yields.

The significant correlation of solar energy with the irrigated forage yield may indicate improved stomatal performance incident to $\mathrm{CO}_{2}$ assimilation.

Merkergrass falls in the same category as sugarcane and corn, with respect to the $\mathrm{CO}_{2}$ fixation pathway, i.e., the $\mathrm{C}_{4}$ dicarboxylic acid cycle. Thus, there are some characteristics that distinguish this group of plants which might not make too critical the common dependence of crops on sunlight and water for an efficient photosynthesis. Black (1) has examined these characteristics when comparing the $\mathrm{C}_{3}(\mathrm{RuDP})$, the CAM, and the $\mathrm{C}_{4}$ groups. Among other photosynthetic-related properties, he mentions the following, which may be pertinent to some aspects of this study: 1) The response of net photosynthesis to increasing light intensity at optimum temperature; 2) $\mathrm{CO}_{2}$ compensation concentration; and 3) transpiration ratio. The first indicated characteristic explains in part the response of all the irrigated forage (irrespective of harvest frequency) to solar energy (table 5). Yet, we may have expected better response from the non-irrigated forage to $R_{i}$. On the other hand, the ability of this group of plants to deplete to a much greater extent the $\mathrm{CO}_{2}$ concentration inside the leaves (2nd characteristic), at least three times more than the $\mathrm{C}_{3}$ group, should compensate to some extent the more frequent stomatal closure of the non-irrigated forage leaves. The ability of these plants to maintain a lower transpiration ratio ( $\mathrm{g}$ $\mathrm{H}_{2} \mathrm{O} / \mathrm{g}$ dry wt), about 2 to $2^{1 / 2}$ times less than $\mathrm{C}_{3}$ plants, also provides a reasoning similar to that of the $\mathrm{CO}_{2}$ compensation concentration in favor of the non-irrigated forage. These apparent inconsistencies suggest a greater support for the overall effect of harvest frequency, reported in the previous study (3).

Therefore, the following multiple regression analysis approach, in which harvest frequency is also considered, was taken as a final step.

It was found that on the irrigated forage, and specifically on low- $\mathrm{N}$ crops, more than one weather index could be used to advantage for prediction of yields. The harvest factor, $H_{f}$, was also found to combine favorably with weather factors to predict the monthly-based forage yields. Table 6 presents the most significant statistical results obtained by multiple regression of the forage yields in each harvest as a function. 
of multiple-weather factors and harvest interval. Only those multiple correlations whose partial regression coefficients were significant, as indicated by their corresponding $t$ values, are presented in table 6 .

The equation, $Y_{H_{2} I_{1} N_{1}}=0.67 T_{m n}-0.58 T_{m x}+1.25 \mathrm{R}_{i}+2.08 \cdots / 1 /$ accounts for $97.1 \%$ of the variation in forage yields of the indicated treatment that may be attributed to fluctuations in the indicated weather indices. This is significant at the $1 \%$ level, and the three partial regression coefficients associated with $T_{m n}, T_{m x}$, and $R_{i}$ are also significant at the levels shown in table 6 . Although the forage yields indicated for equation / $1 /$ can also be predicted nearly as closely when wind speed $(u)$ and vapor pressure deficit $\left(e_{d}\right)$ are introduced into the equation instead of the maximum air temperature, the latter parameter

TABLE 6. - The most significant statistical data obtained by multiple regression of the forage yields as a function of various weather indices and of a harvest factor, $H_{f}$

\begin{tabular}{|c|c|c|c|c|}
\hline Treatment & $\begin{array}{l}\text { Best fit } \\
\text { weather } \\
\text { indices }\end{array}$ & $\begin{array}{c}\text { Coefficient of } \\
\text { determination } \mathrm{R}^{2}\end{array}$ & $F$ value & $\begin{array}{l}t \text { values for partial } \\
\text { regression coefficients }\end{array}$ \\
\hline
\end{tabular}

60-day harvest interval

\begin{tabular}{|c|c|c|c|c|}
\hline $\mathrm{H}_{2} \mathrm{I}_{1} \mathrm{~N}_{1}$ & $\begin{array}{c}T_{m n} \\
-T_{m x} \\
R_{i}\end{array}$ & .971 & $45.41^{* * *}$ & $\begin{aligned} & 6.46^{* *} \\
- & 2.93^{*} \\
& 5.78^{* *}\end{aligned}$ \\
\hline
\end{tabular}

Monthly yields

\begin{tabular}{cllll}
$\mathrm{I}_{1} \mathrm{~N}_{1}$ & $T_{m n}$ & .825 & $23.62^{* *}$ & $3.51^{* *}$ \\
& $R_{i}$ & & & $3.42^{* *}$ \\
& $H_{f}$ & & & $4.22^{* *}$ \\
$\mathrm{I}_{1} \mathrm{~N}_{2}$ & .764 & $16.17^{* *}$ & $2.21^{*}$ \\
& $T_{m n}$ & & $3.13^{* *}$ \\
& $R_{i}$ & & $4.07^{* *}$ \\
\hline
\end{tabular}

* Significant at the $5 \%$ level of probability.

** Significant at the $1 \%$ level of probability.

accounts for greater significance by itself. In fact, $e_{d}$ needed the presence of $u$ to make a significant contribution in helping to predict yields.

In general, the irrigated forage yields of the 60-day harvest intervals $\left(\mathrm{H}_{2}\right)$ were better predicted by the multiple weather components, though in treatment $H_{1} I_{1} N_{1}$ some significant improvement in its yield prediction was obtained by including solar radiation intensity $\left(R_{i}\right)$ with mean air temperature $\left(T_{a}\right)$ in the multiple-regression analysis. Sunlight added $21.5 \%$ contribution in accounting for the $H_{1} I_{1} N_{1}$ yields, beyond what $T_{a}$ alone accounts for $(52.5 \%)$. Yet, although its partial regression coefficient was found significant at the $5 \%$ level, both weather components together caused the partial regression coefficient of $T_{a}$ to become non-significant, possibly because in the case of this 
irrigated treatment, solar energy is more closely related to its yields (table 5). On the other hand, pan evaporation $\left(E_{0}\right)$ alone accounts for $67.5 \%$ of the $H_{1} I_{1} N_{1}$ forage yields in a simple linear regression equation, only $6.5 \%$ less than that which $T_{a}$ and $R_{i}$ together account for in a multiple-regression equation. For these reasons, table 6 does not include this 45-day harvest interval treatment among the most significant multiple-regression equations.

The harvest factor, $H_{f}$, was found to be a favorable inclusion as a management factor in a multiple regression analysis with weather indices, when dealing with the monthly yields of irrigated grass. The minimum air temperature (though generally the mean temperature was nearly as good) and solar radiation were the two weather indices to combine best with $H_{f}$ in multiple regression. No significant improvement in yield prediction was obtained by combining $H_{f}$ with $T_{m n}$ and $R_{i}$ in multiple regression when dealing with non-irrigated monthly forage yields. Thus, an interaction between some weather indices and management (harvest frequency) is apparent when investigated for the irrigated forage at either nitrogen-fertilization rate. The equations

$$
\mathrm{Y}_{I_{\mathrm{i}} N_{1}}=0.20 T_{m n}+0.44 R_{i}+0.28 H_{f}-4.06
$$

and

$$
\mathrm{Y}_{I_{1} N_{2}}=0.18 T_{m n}+0.58 R_{i}+0.39 H_{f}-4.31
$$

account for 82.5 and $76.4 \%$ of the variations in monthly forage yields (19 yields each) that may be attributed to $T_{m n}, R_{i}$, and $H_{f}$, respectively. Their correlation coefficients are .91 and .87 , respectively. The partial regression coefficients of the three independent variables are highly significant on each equation, as shown in table 6 . This is possibly the most noteworthy finding of this study. It has been shown mathematically that, under the present experimental conditions, supplemental irrigation of merkergrass was favorable under the longer harvest interval, yields increasing proportionally with sunlight intensity and minimum temperature.

The former weather index added 13.6 and $15.5 \%$ contribution in predicting the monthly yields beyond that which $T_{m n}$ and $H_{f}$ together contributed. Thus, it is also suggested that the $\mathrm{N}$ application rate contributes to monthly yields depending to some extent on the solar radiation intensity. It finds support in the values of the partial regression coefficients of $R_{i}(0.44$ vs. 0.58$)$ when comparing the low $\mathrm{N}$ equation /2/ with the high $\mathrm{N}$ equation /3/.

\section{RESUMEN}

Se realizó un estudio sobre el efecto de varios índices metereológicos en la composición nutritiva y la producción de yerba Merker como un intento para dilucidar más por qué 
el riego suplementario no tuvo efecto positivo en la producción del forraje cortado cada 45 días, aunque sí aumentó la producción cuando los cortes se espaciaron a 60 días. Consistente con la relación inversa ya informada entre la producción por cortes y el contenido en nitrógeno y potasio en la yerba cortada cada 45 días, este enfoque indica que, además, es significativa e inversa la composición química en función de la intensidad de varios factores climáticos $\left(\mathrm{R}_{\mathrm{l}}, \mathrm{E}_{\mathrm{ta}}, \mathrm{E}_{\mathrm{c}}\right)$.

La relación entre los factores climáticos y la producción fue directa. La temperatura del aire correlacionó directa y significativamente con la producción de todo el forraje; la radiación solar y otros componentes de la demanda por evapotranspiración correlacionaron en forma significativa únicamente con la yerba con riego suplementario.

La regresión múltiple de la producción lograda con varios tratamientos de riego, en función de más de un índice climático mejoró significativamente la predicción de la producción de cada corte. Incluir un factor adicional de frecuencia de corte $\left(\mathrm{H}_{f}\right)$ en la regresión múltiple contribuyó aún más a predecir la producción.

\section{LITERATURE CITED}

1. Black, C. C., Jr., 1973. Photosynthetic carbon fixation in relation to net $\mathrm{CO}_{2}$ uptake, Ann. Rev. Plant Physiol., 24: 253-86.

2. Capiel, M., 1967. The influence of supplemental irrigation and environmental factors on the yield and nutrient composition of napiergrass, Unpublished Ph. D. dissertation, Utah State University, Logan, Utah.

3. —and Asheroft, G. L., 1972. The effect of irrigation, harvest interval, and nitrogen on the yield and nutrient composition of napiergrass (Pennisetum purpureum), Agron. J., 64: 396-8.

4. Gaiza, R., Barnes, R. F., Mott, G. O., and Rhykerd, C. L., 1964. Influence of light intensity, temperature, and growing period on the growth, chemical composition and digestibility of Culver and Tannerde alfalfa seedlings, Agron. J., 57: 417-20.

5. Hart, R. H., and Burton, G. W., 1965. Effect of weather on forage yields of winter oats, rye, and wheat, Agron. J., 57: 588-91.

6. Lenkel, W. A., 1927. Deposition and utilization of reserve foods in alfalfa plants, J. Amer. Soc. Agron., 19: 596-623.

7. Penman, H. L., 1948. Natural evaporation from open water, bare soil, and grass, Proc. Royal Soc. London, 193: 120-46.

8. Tanner, C. B., and Pelton, W. L., 1960. Potential evapotranspiration estimates by the approximate energy balance method of Penman, J. Geophys. Res., 65: 3391417.

9. Weihing, R. M., 1963. Growth of rye-grass as influenced by temperature and solar radiation, Agron. J., 55: 519-21. 